\title{
Konaklama ve Seyahat İşletmelerinde Yaşanan Etik Sorunlar Üzerine Kavramsal Bir Değerlendirme ${ }^{1}$ \\ A Conceptual Assessment of Ethical Problems in Accommodation and Travel Operations
}

\author{
Atınç OLCAY* \\ Burçin ÖZKAN** \\ Mehmet Fatih GÖÇEBELER***
}

$\ddot{O} z$

Bu çalışmanın amacı, konaklama ve seyahat işletmelerinde yaşanan etik sorunların belirlenmesi; ahlak ve etik kavramlarının tanımlanması ve turizm işletmelerinde etik kuralların neler olduğunun ortaya konulmasıdır. Bu kapsamda etik kavramı ve etik türlerine değinilmiş; söz konusu işletmelerde meydana gelen etik sorunlar ele alınmıştır. Etik, turizm sektörü açısından oldukça önemli bir konudur. Turizm sektörü bünyesinde yer alan konaklama ve seyahat işletmeleri turizmin faaliyet alanlarıdır. Seyahat işletmeleri insanlara seyahate çıkmadan önce ve seyahatleri boyunca yardımcı olan işletmelerdir. Bu bağlamda, müşterisine gidilen destinasyon hakkında aslında var olmayan bir ürünün var olduğunu söyleyen bir seyahat işletmesi çalışanı bu etik dışı davranışı nedeniyle, müşterisinin söz konusu acentayı bir daha tercih etmemesine neden olmaktadır. Konaklama işletmelerinde ise müşteri ile işletme personelinin uzun saatler boyunca bir arada bulunmaları ve müşterilerin can ve mal güvenliğinin konaklama işletmesinin sorumluluğunda olması gibi nedenlerden dolayı, turizm etik olarak incelenmesi gereken bir alandır. Bu çalışmada ilgili alanyazın taraması yapılmış, araştırmacıların sektör tecrübelerinden yararlanılmış ve konuyla ilgili yapılmış önceki çalışmalara yer verilmiştir. Araştırmanın sonucunda en fazla göze çarpan etik sorunların; aldatıcı ve yanıltıcı nitelikteki haberler, fazla rezervasyon, çalışanlarla ilgili sorunlar ve cinsel sorunlar olduğu görülmektedir. Bu doğrultuda söz konusu işletme yöneticilerine ve turizm eğitimi veren kurumlara çeşitli önerilerde bulunulmuştur.

Anahtar Kelimeler: Konaklama ve Seyahat İşletmeleri, Turizm, Etik, Etik Sorunlar.

\begin{abstract}
The aim of this study is to determine the ethical problems experienced in accommodation and travel establishments; to define the concepts of ethics and ethics and to determine the ethical rules in tourism enterprises. In this context, the concept of ethics and ethics are mentioned. ethical problems in these enterprises are discussed. Ethics is a very important issue for the tourism sector. Tourism and travel companies within the tourism sector are the areas of activity of tourism. Travel businesses are businesses that help people before traveling. In this context, a travel business employee who tells his customer that there is a product that actually does not exist about the destination is causing his / her customer to not choose this agency again due to this unethical behavior. In accommodation establishments, tourism is an area that needs to be examined ethically due to the fact that the customer and operating personnel are together for long hours and the customers' life and property are the responsibility of the accommodation operation. In this study, the related literature was searched and the sector experiences of the researchers were utilized and previous studies on the subject were included. As a result of the research, the most conspicuous ethical problems; deceptive and misleading news, excessive reservations, problems with employees and sexual problems. In this respect, various suggestions have been made to these managers and tourism training institutions.
\end{abstract}

Key Words: Accommodation and Travel Operations, Tourism, Ethics, Ethical Issues.

\section{Giriş}

Günümüzde doğru, özgür, eşit, adil, temiz ve daha yaşanılır bir dünya özlenmektedir. Her ne kadar şikayet etseler de insanlar bilinçli ya da bilinçsiz olarak yozlaşma ve kirlenmeye katkıda bulunmakta ve herşeyi eleştirirken kendilerini savunmaktadırlar. Victor Hugo'nun da

\footnotetext{
${ }^{1}$ Bu çalışma 9-10-11/05/2018 tarihleri arasında Gaziantep Üniversitesi’nde gerçekleştirilen Uluslararası Etik Araştırmaları Sempozyumunda bildiri olarak sunulmuş ve revize edilerek makale formatına dönüştürülmüştür.

* Doç Dr. Gaziantep Üniversitesi, Turizm İşletmeciliği Anabilim Dalı, olcay@ gantep.edu.tr.

** Yüksek lisans öğrencisi, Gaziantep Üniversitesi, Sosyal Bilimler Enstitüsü, Turizm İşletmeciliği Anabilim Dal1, burcinozkan92@gmail.com.

*** Yüksek lisans öğrencisi, Gaziantep Üniversitesi, Sosyal Bilimler Enstitüsü, Turizm İşletmeciliği Anabilim Dalı, fatihgocebeler@gmail.com.
}

Olcay, A., Özkan, B., Göçebeler, M. F., (2018). Konaklama ve Seyahat İşletmelerinde Yaşanan Etik Sorunlar Üzerine Kavramsal Bir Değerlendirme, Gaziantep University Journal of Social Sciences, 17 Etik Özel Sayı, 1-11, Submission Date: 24-04-2018, Acceptance Date: 24-12-2018.

Araştırma Makalesi. 
dediği gibi; "herkes insanlığ 1 değiştirmeyi düşünüyor ama maalesef kimse kendisinden başlamıyor" sözü insanların etik davranışlar konusundan kendilerini sorgulamadıklarını açıkça göstermektedir (Şahin, 2011, s. 1). İdeal ve soyut olana işaret eden etik kavramı, insanlar arasındaki temel ilişkileri yorumlayan felsefenin ahlaki değerleri inceleyen bir dalı olarak görülmektedir (Ekiztepe, 2011, s. 1). Etik, Yunanca "ethos" kelimesinden türetilmiştir. Bir insanın hayata karşı temel yönelimi anlamına gelir. Etik, ahlaki yargıları sistemleştirmeye çalışan bir ahlak teorisi olarak tanımlanabilir (Sroka ve Lörinczy, 2015, s. 157).

Konu turizm açısından ele alındığında, sektörün kendine özgü yapısı çok sayıda müşteriye hizmet sunması, müşteri-çalışan arasındaki yakın ilişki sebebiyle sektör etik açıdan özenli bir yaklaşımı beraberinde getirmektedir. Bu sebeple turizm faaliyetlerinin etkinliğinde ve turistin tatmin olmasında; etik ve ahlak kurallarına uyarak, turistleri aldatmadan güvenilir bir hizmet sunmak gerekmektedir. Bu sayede müşteri memnuniyeti oluşmakta ve müşterilerin işletmeyi tekrar tercih etmeleri sağlanmaktadır. Ayrıca sektörün insan odaklı yapısı bu alandaki hizmetlerin sunumunda misafirperver davranışlar, nezaket ifadeleri, başkalarına iyi davranmak ve huzuru sağlama gibi temel etik değerlerin dikkate alınmasının önemine işaret etmektedir. $\mathrm{Bu}$ nedenle turizm endüstrisinin başarısında ve toplum tarafından bu endüstrinin algılanışında etik değerlere sahip olmanın, müşterinin beklentilerini etik değerlere uygun karşılamanın, bunu özümsemenin ve uygulamanın büyük önemi vardır (Aydın vd., 2016, s. 21).

\section{Etik ve Ahlak Kavramları}

Etik, bir kişiye, filozofa ya da kuruma özel ahlak görüşüdür. Ruddell'e (2004) göre etik; yapmamız gereken ve iyi olan şeyin değişmez ve evrensel standardıdır (Torun, 2013, s. 3). Etik, Ahlaki olarak iyi ve kötü ya da doğru ve yanlış nedir? gibi sorulara yanıt arayan bir sistemdir. Ayrıca etik, kişinin davranışlarına temel olan ahlak ilkelerinin tümü olarak da tanımlanmıştır (Öncel, 2010, s. 12).

Beauchamp ve Bowie (1993) etiği şöyle tanımlar; iyinin ve kötünün, doğrunun ve yanlışın teorilerini soruşturan, dolayısıyla ne yapmamız ve ne yapmamamız gerektiğini sorgulayan bir sistemdir. Runes (1964) ise etiği, benzer şekilde ' ahlaki davranışlar'” şeklinde ifade etmiştir. Bir diğer tanıma göre ise etik "taraflar arasında adil ya da doğru davranış standartları'’dır. Barry (1979)'nin çalışmasına göre ise etik, iyi ve kötü insan davranışlarını oluşturan eylemler ve değerleri inceler (Tsalikis ve Fritzsche, 1989, s. 696).

Etik nedir? sorusunu cevaplamak oldukça zordur. Yine de birçok etik tanımına rastlamak mümkündür. Etik kavramının tanımlarına bakıldığında birçok araştırmacı farklı noktalara dikkat çekmiştir. Tanımların birbirinden farklı olmasının nedeni, tanımlayan kişinin sahip olduğu etik değerlerindeki, dini inancındaki ve duygularındaki farklılıktan, bireyin ilgilendiği dal ve toplum içindeki rolünden kaynaklanabilmektedir (Meriç, 2013, s. 47).

Ahlak, TDK'nın sözlüğüne göre bir toplumda insanların uyması gereken davranış kalıpları olarak tanımlanmaktadır (www.tdk.gov.tr). Arapça kökenli hulk kelimesinden türemiş olan ahlak, huy, mizaç, yaratılış anlamlarına gelmektedir. Toplumda insanların birbirleriyle olan ilişkilerinde uymaları gereken kurallar bütünüdür. İnsanı ahlaklı olmaya iten vicdani duygulardır (Demirçivi, 2013, s. 2).

İnsanlar daha mutlu bir yaşam sürdürebilmenin temellerinin ahlak ile mümkün olduğunu düşünmektedirler. Bu da gerekli etik davranış ve kuralların gerçekleştirilmesiyle mümkün olabilecektir. Ahlak kurallarının temelinde doğru ya da yanlış1, iyi veya kötüyü seçimlerini saptamak ve standartlarını belirlemek içindir (Velasquez, 2002, s. 8).

Etik ve ahlak kelimeleri çoğu zaman karıştırılmakta ve aynı anlama gelecek şekilde kullanılmaktadır. Hatta bazı yazarlar etik kavramının karşılığının ahlak olduğunu savunmaktadırlar. Etik ve ahlakı birbirinden ayıran nokta ise etiğin ahlaki ilkelere karşı 
eleştirici bir yapısı olmasıdır. Ahlak, etiğin araştırma konusudur yani etiğin görevi ahlakı incelemektir. Etik, ahlakı inceleyen bir felsefe disiplinidir (Meriç, 2013, s. 48; Akyol, 2010, s. 6-7).

\section{Etik Türleri}

Etik türlerini bireysel etik, örgütsel etik, yönetsel etik ve mesleki etik olarak dört şekilde sınıflandırmak mümkündür (Menekşe, 2007, s. 33):

- Bireysel Etik

Bireysel etik, bir insanın iyi ve doğrunun ne olduğuna ilişkin kişisel değer ve inançlarının mevcut kuralların etkisiyle oluşmasıdır (Akoğlan Kozak ve Güçlü, 2006, s. 41).

- Örgütsel Etik

Örgütsel etik, aynı yerde çalışmakta olan bireylerin istek ve amaçlarının gerek birbirleriyle gerekse örgütünkiyle uyumlu hale gelmesi olarak tanımlanabilir. Bireylerin davranış ve tutumları, üyesi oldukları örgütün hedefleriyle tutarlılık göstermelidir. Ancak bu durumda hem bireyler hem de örgütler hedeflerine ulaşabileceklerdir (Uçkun vd., 2004, s. 11).

- Yönetsel Etik

Yönetsel etik, yöneticilerin karar alma sürecinde etik ilke ve kurallara uygun faaliyetlerde bulunmaları konusunda onlara rehberlik eden davranış standartlarıdır (Demirçivi, 2013, s. 21).

\section{- Mesleki Etik}

Mesleki etik, bir meslek grubunun uymak zorunda olduğu ve kaçınması gereken davranışlardır (www.tdk.gov.tr). Mesleki etik, iş ahlakının önemli bir kısmını oluşturmaktadır (Torun, 2013, s. 16).

\section{Turizm Sektörü ve Etik}

Turizm sektörü emek yoğun bir sektördür. İnsanların ihtiyaçlarının karşılanması amacıyla üretim unsuru yani hizmet ön plandadır. Turizmin hizmet sektörü olması, yani insanın insana hizmet etmesi iletişimi kaçınılmaz kılmaktadır. Dolayısıyla işletmedeki müşteri ve çalışanlar yakın ilişki halinde olduklarından turizm işletmelerinde etik unsuru çok önemlidir. Çünkü müşteriler ve çalışanlar yüksek oranda farklı kültürlerden olabilmektedir. Bu iki kesimin etik anlayışları birbirinden farklıdır. Müssterilerin çalışanlar ile aşırı samimi olmaları dolayısıyla çalışanlar, genellikle etik bulmadıkları bu durumdan olumsuz etkilenmektedirler.

Ülkemiz açısından turizm, çok önemli bir döviz kaynağıdır. Ekonomiye böylesine katkı sağlayan bir alanda rekabet de söz konusudur (Akova ve Çalık, 2008, s. 4). Turizmdeki rekabet sebebiyle, tüketiciyi yanlış yönlendiren reklamlarla karşılaşılabilmektedir. Fakat tüketicileri aldatan bu reklamlar, sunulan hizmetten hoşnut kalınmamasına neden olmaktadır. Seyahat ettiği acentadan memnun kalmayan bir müşteri, bir sonraki seyahatinde söz konusu acentay tercih etmemekte, hatta bu olumsuz durum yüzünden aynı ülkeye bir daha seyahat etmememe kararı almaktadır (Altuğ ve Güler, 2003, s. 325).

Turizm işletmelerinde müşteri ve çalışan arasında yaşanan sorunları çözümleyebilmek için etik değerler oluşturulabilmek, çalışanlara benimsetebilmek ve uygulayabilmek üzerine yabancı literatürde birçok kaynak bulunmaktadır. Fakat bu alanda Türkiye'de yapılan araştırmalar sınırlı sayıdadır (Y1lmazer ve Bahadır, 2011, s. 25). Uluslararası ve ulusal yasa ve sözleşmelerle müşteri ve çalışanların etikle ilgili hak ve sorumlulukları belirlenmiştir. $\mathrm{Bu}$ nedenle yöneticiler etik politika ve kurallar belirlemekte, çalışanlarına benimsetmekte ve değişen koşullara göre bu kuralları güncellemektedirler (Sarışı1k vd., 2006, s. 24). 


\section{Turizm Sektöründe Etik Sorunlar ve Etik Dıșı Davranışlar}

Turizm sektöründe gerek müşterinin gerekse çalışanın sergilediği bazı etik dışı davranışlar vardır. Restoranda çalışan personelin müşteri büfesinden yemek alması, kat hizmetleri personelinin temizlik amaçlı girdiği odada müşterinin eşyalarına amacı dışında dokunması, önbüro personelinin döviz bozma işlemini işletmenin kasasından yapmayarak kişisel kazanç elde etmesi gibi örnekler bunlardan bazılarıdır.

Turizm alanında bahsedilen etik dışı uygulamalar, özellikle gerçek dışı tanıtımlar, fiyat politikası, kapasite fazlası rezervasyon (overbooking), ahlaka uygun olmayan şekilde eğlenme, sosyo-kültürel farklar nedeniyle oluşan durumlar üzerine yoğunlaşılmıştır (Şahin, 2011, s. 265).

Turizm işletmelerinde yaşanan etik sorunlardan bir diğeri ise cinsel sorunlardır. Turizmde hizmet sunumu müşteriyi memnun etme esasına dayandığı için çalışan kişinin samimi ve içten davranışları bazen müşteri tarafından yanlış algılanmaktadır. Müşterilerin uygunsuz ve hoş olmayan beklentileri olabilmektedir (Şahin, 2011, s. 275). Turizm işletmelerinde yaşanan diğer bir etik sorun da cinsel tacizdir. Bay veya bayan fark etmeksizin birçok çalışan üstlerinin tacizine maruz kalmaktadır. Seks karşılığında terfi vermeyi teklif etmek gibi etik olmayan durumlar yaşanabilmektedir. Etik kuralların olduğunu söyleyen hiçbir işletme bu durumlara izin vermemelidir. Ağırlama işletmelerinde müşterilerin işgörenlere yaptıkları tacizler diğer bir etik sorundur (Tarakçıoğlu, 2003, s. 191).

\section{Turizmde Etik Kurallar}

Birçok araştırmacının turizm etik ilkelerin oluşturulmasında hemfikir olduğu görülmektedir. Konuyla ilgilenmiş araştırmacıların çeşitli çalışmaları incelendiğinde, turizm sektöründeki etik kurallar aşağıda verildiği gibidir (Yılmazer ve Bahadır, 2011, s. 26):

- Saygil1, dürüst ve tarafsiz olmak,

- İyi, adaletli ve eşit olmak,

- İnsanların özel hayatına saygı duymak,

- Görevlerinin bilincinde olup, sorumluluğunu alabilmek.

\section{Konaklama İşletmelerinde Etik Sorunlar}

Konaklama işletmeleri, müşterilerin yalnızca konaklayıp yemek yedikleri yerler değildir. Müşteriler bu işletmelerde sosyal ihtiyaçlarını da karşılarlar. Ayrıca işletme çalışanları ve müşteriler uzun saatler boyunca aynı mekanda bulunmaktadırlar. Bu nedenle konaklama işletmelerinde sosyal ilişkiler yoğun olarak yaşanmaktadır. Müşteri ve çalışanların farklı kültürel özelliklere sahip olmaları nedeniyle etik beklentiler de farklıdır (Kılınç, 2000, s. 96). Konaklama işletmelerinde her departmanın etik açıdan sorumlulukları vardır. Yapılan araştırmalar doğrultusunda önbüro, kat hizmetleri, yiyecek ve içecek, muhasebe ve güvenlik departmanlarında yaşanan etik sorunlar ve söz konusu departmanların sorumlulukları aşağıda özetlenmiştir.

\section{Önbüro Departmanı ve Etik}

Önbüro, müşterinin söz konusu olan konaklama işletmesinde ilk karşılaşacağ 1 bölümdür. Dolayısıyla müşteri ile ilk iletişim kuracak kişi de önbüro personelidir. Bu durum müşterinin ilk izlenimini oluşturmaktadır. İlk izlenim ise işletme için çok önemlidir. Bu nedenle önbüro bölümü, diğer bölümlere nazaran daha nitelikli personele gereksinim duyar. $\mathrm{Bu}$ bölümde çalışan personelin üstlenmiş olduğu görev sorumluluğunun bilincinde etik değerleri ön planda tutarak bireysel etik anlayışını iş etiği ile birleştirebilme yeteneğine sahip olması 
gerekir (Karayiğit, 2004, s. 60). Önbüro bölümünde ortaya çıkan etik sorunları gündeme getiren konular aşağıdaki gibidir;

Rezervasyon: Müşterilerin seyahat etmeden önce kalacakları yeri ayırtma işlemine rezervasyon denir. Rezervasyon memurunun sorumluluğu müşteriye konaklama seçeneklerini olduğu şekliyle sunmaktır. Örneğin; müşterinin beklentisini daha uygun fiyatlı bir oda karşıladığı halde müşteriye yüksek fiyatlı bir oda önermesi etik olmayan bir durumdur. Ayrıca müşteriye odadaki minibarın ekstra olduğu söylenmediği takdirde, müşteri otele geldiğinde hayal kırıklığına uğrayacaktır. Bu durum hem memnuniyetsizliğe hem de etik sorunlara sebep olacaktır (Sürme, 2015, s. 29-30).

Overbooking: İşletmenin mevcut oda miktarından daha fazlasını satmasına denir. İşletmeler bunu genellikle kendilerini garantiye almak için gerçekleştirirler. $\mathrm{Bu}$ durum işletmenin müşteriye karşı mahcup duruma düşmesine neden olmaktadır. Çünkü dolu olan bir otelde hali hazırda rezervasyonu bulunan bir müşteriyi çevredeki bir başka otele göndermek etik değildir. Diğer bir etik sorun ise münferit konukların kabulünde karşılaşılan durumdur. Önbüro personelinin rezervasyon yapılmış bir odayı münferit konuğa satması ya da konuktan daha yüksek bir fiyat talep etmesi buna örnek olarak verilebilir (Karayiğit, 2004, s. 61).

\section{Kat Hizmetleri Departmanı ve Etik}

Konaklama işletmelerinde etik sorunların yoğun olarak yaşandı $\breve{g ̆}_{1}$ bir alan kat hizmetleridir. Müşterilerin işletmeye ve çalışanlarına güvenerek özel eşyalarını bıraktığı odasında bu eşyaların kat hizmetleri personeli tarafından kullanımı veya çalınması etik olmayan durumlardır. Ayrıca müşteri odalarına usulsüz girilmesi, odaların dinlenmesi ve müşterilerin gözetlenmesi personelin etik dışı davranışları arasındadır. Önemli bir konu da müşteri bilgilerinin gizli tutulmasıdır. Yasal durumlar haricinde bu bilgiler kimse ile paylaşılmamalıdır (Sürme, 2015, s. 30-31).

\section{Yiyecek ve İçecek Departmanı ve Etik}

Yiyecek ve içecek departmanı turizm işletmelerinde sahip olduğu görev ve sorumluluklar bakımından son derece önemli bir departmandır. Bu nedenle bu departmanda çalışanların müşterilere karşı tavır ve davranışları işletmenin imajı açısından önem arz etmektedir. Yiyecek ve içecekler ile ilgili etik konularda ise sanitasyon ve güvenlik ile menülerde doğruluk öne çıkmaktadır (Karayiğit, 2004, s. 63-64).

Yiyecek-içecek bölümünde istihdam edilen hem yöneticilerin hem de çalışanların sanitasyon ve güvenlik konusunda hassasiyet göstermeleri gerekmektedir. Yiyecek ve içeceklerin temininden başlayarak hazırlanmasına kadar tüm evrelerde hijyen sağlanmalıdır. Aksi taktirde yiyeceklerden kaynaklanacak zehirlenme gibi durumlar ortaya çıkabilir. Müşterilerin sağlık ve güvenliği tehlikede olduğunda, işletme hem prestij kaybı yaşamakta hem de yasal yaptırımlarla karşılaşmaktadır (Karayiğit, 2004, s. 64). Yiyecek içecek bölümünde önemli bir diğer etik sorun menülerle ilgilidir. Yiyecek-içecek işletmelerinde sunulan yiyecek ve içecekler menülerdeki cinsi, ismi, miktarı ve fiyatı menüde yazıldığı gibi olmalıdır. Menülerde doğruluk müşteri tarafından üzerinde en fazla durulan konulardandır (Akoğlan Kozak ve Güçlü, 2006, s. 91).

\section{Muhasebe Departmanı ve Etik}

Muhasebe departmanı sadece turizm sektöründe konaklama işletmeleri için değil bütün işletmelerde oldukça önemli bir yere sahiptir. Muhasebe departmanı genel olarak işletmenin mali özellikteki işlerini yürütür. Bu yüzden muhasebe deaprtmanı etiksel sorunların merkezinde yer alır. Genelde mali işlerde raporlama işlevini yerine getiren muhasebe departmanı bu işlevi yerine getirmek için bir çok departmanlada işbirliği içinde olur. Muhasebe departmanın yerine 
getirdiği işlemler yasalarla belirlidir. Bundan dolayı muhasebe departmanın ilk görevi içinde bulunduğu bölgenin yasalarını iyi bilmektir. Hemen hemen bütün sektörlerde olduğu gibi, turizm sektöründe de muhasebe departmanının sahip olduğu roller sistem analizi, vergi uzmanlığı, finansal analizler, kontrol etme, memurluk gibi vasıflardan oluşmaktadır. Bu sebeble muhasebe departmanında çalışanların birden fazla alanda becerili olması beklenmektedir. İşletme sahiplerine bağlı olarak çalışan muhasebe elemanları, işletmenin istediği şekilde çalışmak mecburiyetinde kalmaktadır. Çalışanlar işinden olmamak için etik olmayan bazı uygulamalara göz yummakta, yasal mevzuatı çalışma prensiplerine uydurarak ve kanunların boşluklarını işletme lehine kullanarak bireysel etik inançlarından uzaklaşmaktadırlar (Şahin, 2011, s. 320-323). Konaklama işletmelerinin muhasebe departmanında karşılaşılan etik sorunlar şu şekilde sıralanabilmektedir (Şahin, 2011, s. 322323):

- Kullanılmayan odaların envanter dişında tutulması

- İndirim tarihi geçtiği halde faturalarda indirim alınmış gibi yapmak

- İşletme cirolarını olandan daha yüksek göstermek

- Çalışanlara yapılan zamların bir süreliğine uygulanmaması

- Bazı maliyetlerin farklı şekillerde yasallaştırılması

- Misafir maliyetlerinin misafirlerin bilgisi dışında yükseltilmesi

- Menüdeki yiyecek-içeceklerin maliyetlerinin düşdüğü halde menülerdeki fiyatlara yansimamasi.

\section{Güvenlik Departmanı ve Etik}

Konaklama işletmelerinde sıklıkla karşılaşılan hırsılılı sorunu güvenlik bölümünü yakından ilgilendirir. Güvenlik personeli her koşulda gerçeği ortaya çıkarmalıdır. Hırsızlık gibi durumlarda kesin kanıt olmadan kimseyi suçlamamalıdır. Kanıtsız bir şekilde kişiyi zanlı olarak deşifre etmek etik dışı bir davranıştır. Kaza, hırsızlık ve ölüm gibi olaylar karşısında güvenlik departmanı personeli paniğe neden olacak söz ve davranışlardan uzak durmalıdır. Meydana gelen hırsızlık, kaza ve ölüm gibi istenmeyen durumlardan ilk etapta otel müdürü haberdar edildikten sonra yetkililer durum hakkında bilgilendirilmelidir. Tüm bunların paralelinde olay yeri ile ilgili deliller açısından yetkililer dışında kimsenin bu yerlere yaklaşmasına güvenlik personeli izin vermemelidir (Karayiğit, 2004, s. 78-79).

\section{Seyahat İşletmelerinde Etik Sorunlar}

Turistler seyahat etmeden önce hayalini kurdukları, farklı, sıra dışı, maceralı ve gizemli bir tatil deneyimi kazanmak isterler. Seyahat işletmeleri de müşterilere hayalini kurdukları tatilini sunmaya söz vermektedir (Yarcan, 2007, s. 39).

Acentalar turistlere tatil yapmak istedikleri yerler hakkında fikir verme ve tavsiyelerde bulunma niteliklerinden dolayı turizm sektöründe önemli bir role sahiptir. Turistlerin tercih ve kararlarını etkileyen en önemli unsurlar seyahat işletmelerinin müşterilere bilgi sunmaları ve imaj oluşturmalarıdır. Seyahat acentaları, tüketicilere uzman bilgisi sunarak onları etkileyebilirler. Seyahat acentaları kimi zaman var olmayan bir ürün ya da hizmeti, daha çok müşteriye ulaşmak amacıyla o ürünün/hizmetin var olduğunu söyleyebilmektedirler. Etik açıdan düşünüldüğünde daha fazla kâr elde edebilme amacıyla gerçekleştirilen bu eylem etik dışı bir davranış olarak karşımıza çıkmaktadır. Seyahat işletmelerinde karşılaşılan etik sorunlar genel olarak paket turlar, ulaştırma ve çalışanlarla ilgili sorunlardır (Şahin, 2011, s. 332). 


\section{Paket Turlarla İlgili Etik Sorunlar}

Turizme yönelik ürün ve hizmetlerin toplu halde bir bütün olarak, tek bir paket halinde ve hazır bir şekilde müşterilere sunulduğu seyahatler paket tur olarak tanımlanmaktadır. Müşteriye söz verilen hizmetlerin yerine getirilmemesi paket turlarda etik sorunların başında gelmektedir. Turizm sektöründe hizmetlerin, üretim ve tüketimi aynı anda gerçekleştiğinden müşterilere nasıl sunulduğu ve personelin davranış şekli önem taşımaktadır (Aşar, 2018, s. 53). Seyahat acentaları tarafından müşterilere satılan paket turlarla ilgili etik olmayan durumlar şu şekilde sıralanabilir (Aşar, 2018, s. 53-54):

- Müşteri seyahate çıkmadan önce ücreti peşin öder. Fakat seyahate katılmaz ise genellikle geri ödeme yapılmaz veya çok düşük bir kısmı müşteriye geri ödenir,

- Broşür ve reklamlarda tüketicilere birtakım hizmetler vaad edilir. Fakat konaklama yapılacak otel bu hizmetleri karşılamayabilir,

- Kahvaltı veya öğle/akşam yemeği hizmetleri eksik yapılabilir veya ekstra olabilir,

- Vaad edilen ulaşım hizmeti yerine getirilmeyebilir,

- Rehber ya da acenta çalışanı tarafından gidileceği söylenen destinasyonlara gidilmeyebilir,

- Tatil bitiminde olumsuz görüşleri paylaşmak için bir yetkili bulunamayabilir.

\section{Ulaştırmayla İlgili Etik Sorunlar}

Seyahat ederken tercih edilen en yaygın ulaşım şekli havayoludur. Havayolu şirketleri zaman zaman farklı fiyat politikaları uygulamaktadırlar. Bu uygulamaların başlıcaları grup indirimleri, hafta içi ve hafta sonu fiyat farklılıkları, ölü ve yoğun sezonda fiyatların farklılaştırılması durumlarıdır. Bu fiyat farklılıları etik açıdan tartışılması gereken bir konu olmaktadır (Sürme, 2015, s. 34).

\section{Çalışanlarla İlgili Etik Sorunlar}

Acenta çalışanlarının en önemli görevlerinden biri müşterilere bilgi vermektir. Çünkü verilen hatalı ya da eksik bilgiler müşterinin işletmeye olan güvenini zedelemektedir (Sürme, 2015, s. 33). Müşteri ve çalışanın sıklıkla bir arada bulunduğu turizm sektörü kişisel ilişkiler oluşmasına zemin hazırlamaktadır. Personelin müşteriye sunduğu ayrıcalıklı hizmet karşılığında müşteriden hediye veya rüşvet alması etik olmayan bir durumdur. Bununla birlikte personelin hizmet paketine dahil olmayan bir hizmeti daha fazla bahşiş alabilmek amaciyla müşteriye sunması bir diğer etik dışı davranıştır (Akova ve Çalık, 2008, s. 5).

\section{İlgili Araştırmalar}

İnsan ilişkilerinin yoğun olduğu turizm sektöründe, insanlar çalışan ya da müşteri olarak bir arada bulunmaktadırlar. Hizmet talep edenlerle hizmete yanıt verecek kesim arasındaki en önemli köprü etik değerlerdir (Sürme, 2015, s. 28). Genel olarak turizm işletmelerinde yaşanan etik sorunlarla ilgili yapılan araştırmalar, yönetici ve işgörenlere yöneliktir (Wong, 1998; Yeung, 2004; Akova ve Çalık, 2008; Menekşe, 2008; Y1lmazer ve Bahadır, 2011; Lee ve Tsang, 2013; Ma vd, 2013; Olcay ve Sürme, 2015).

\section{Yurtiçinde Yapılmış Araştırmalar}

Akova ve Çalık (2008), turizm eğitimi alan öğrencilerin sektörde ortaya çıkan etik dışı uygulamaları nasıl algıladıklarını belirlemek amacıyla Sakarya Üniversitesi'nde bir araştırma gerçekleştirmişlerdir. Araştırma sonucunda katılımcıların turizm sektöründe oluşan etik dış1 olaylara katılmadıkları fakat müşterilerin hassas oldukları etik dışı davranışlarda ise esnek 
oldukları görülmüştür. Ayrıca, yaş, deneyim ve eğitim değişkenlerine göre etik dışı davranışlara bakış açısı neredeyse paralellik gösteriken, cinsiyet değişkeninde diğerlerine oranla daha fazla anlamlı farklılıklar bulunmuştur.

Menekşe (2008), seyahat acentalarında çalışan personelin tüketiciye karşı etik davranışları algılama düzeylerinin tespit edilmesi amacıyla Ankara'da çalışmakta olan 232 çalışan üzerinde bir araştırma gerçekleştirmiştir. Araştırma sonucunda, cinsiyet, eğitim durumu ve mesleki eğitim değişkenlerinin etik kavramını algılamada anlamlı farklılıklar oluşturan faktörler olduğu görülmüşsür.

Y1lmazer ve Bahadır (2011), otel işletmelerinde önbüro departmanında çalışan personellerin etik algılamalarını ve görüşlerini ortaya koymak amacıyla İstanbul'da bir çalışma gerçekleştirmişlerdir. Araştırma sonucunda personellerin etik algılama düzeyleri makul düzeyde olduğu tespit edilmiștir. Ayrıca önbüro personelini etik dışı davranmaya iten nedenlerin başında yönetici ve işletme sahipleri gelmektedir. Bununla birlikte personelin meslek eğiti hakkında yeterli bilgiye sahip olmadığı görülmüştür.

Olcay ve Sürme (2015), turizm işletmelerinde yönetici ve işgören etik davranışlarının stajyer öğrenci bakış açısıyla değerlendirmek amacıyla Gaziantep Üniversitesi Turizm ve Otelcilik Meslek Yüksekokulu ile Gaziantep Üniversitesi Güzel Sanatlar Fakültesi Gastronomi ve Mutfak Sanatları bölümlerine kayıtlı 308 öğrenci üzerinde bir araştırma gerçekleştirmişlerdir. Araştırma sonucunda stajyer öğrenci gözüyle, yönetici ve işgören etik davranışlarının, istatiksel olarak anlamlı bir farklılık bulunmuştur.

\section{Yurtdışında Yapılmış Araştırmalar}

Wong (1998), çalışanların etik ilkeleri algılama düzeylerini belirlemek amacıyla amacıyla Çin'in Hong Kong şehrinde 3-4-5 yıldızlı 30 adet otel işletmesinde bir araştırma gerçekleştirmiştir. 299 kişi üzerinde yapılan bu araştırma sonucunda 18-25 yaş grubu işgörenlerinin daha yaşlı olan işgörenlere oranla etik dışı davranışlara karşı daha toleranslı olduğu görülmüştür. Ayrıca eğitim seviyesi yükseldikçe etik ilkelere verilen önemin de buna paralel olarak arttığ 1 tespit edilmiştir.

Yeung (2004), etik kodların önemini ortaya koymak amacıyla otel işletmeleri bünyesinde çalışan 308 yönetici üzerinde bir araştırma gerçekleştirmiştir. Yapılan araştırma sonucunda toplam 8 faktör tespit edilmiştir. Bunların en önemlilerinin cinsel taciz ve işletme mamüllerinin çalınması olduğu belirlenmiştir.

Ma vd. (2013), turizm alanında staj yapan öğrencilerin iş eğiti görüşlerinin tespit edilmesi amacıyla Çin'de bir araştırma gerçekleştirmişlerdir. Araştırma sonucunda erkek öğrencilerin kız öğrencilere oranla etik değerlere daha az önem verdiği sonucuna ulaşılmıştır.

Lee ve Tsang (2013), turizm öğrenimi gören öğrencilerin etik görüşlerini tespit etmek amacıyla Çin'in Hong Kong şehrinde bir araştırma gerçekleştirmişlerdir. Araştırma neticesinde önlisans ve yüksek lisans öğrencilerinin, lisans öğrencilerine oranla etik dışı davranışları kabul etme durumlarının daha düşük olduğu görülmüştür. Fakat öğrencilerin genelinin etik bilgi düzeyleri yüksek olduğu bir diğer sonuçtur.

\section{Sonuç ve Tartışma}

Bu çalışmanın asıl amacı, konaklama ve seyahat işletmelerinde yaşanan etik sorunların belirlenmesi ve turizm işletmelerinde etik kuralların neler olduğunun ortaya konulmasıdır. Araştırmadan çıkarılan sonuçlar doğrultusunda bazı açıklamalarda bulunmak yerinde olacaktır.

Konaklama işletmesi bünyesinde yer alan önbüro departmanında bazı etik sorunlar yaşanmaktadır. Otellerin kendilerini garanti altına almak için uyguladıkları overbooking 
sistemi bazı etik sorunlara neden olmaktadır. Otel ișletmesi talebi karșıyamadığ kendi müşterisini çevre otellerde konaklatmak zorunda kalmaktadır. Öte yandan müşterilerin iptal etmek istedikleri rezervasyonları zamanında haber vermemesi nedeniyle işletmelerin böyle bir yönteme başvurması kaçınılmazdır. Yine konaklama işletmesi bünyesinde çalışan kat hizmetleri görevlisinin nevresim takımını değiştirmemesi gibi bir yanlış davranışı, müşterinin otel hakkında olumsuz düşünmesine ve söz konusu oteli bir daha tercih etmemesine neden olabilmektedir. Bu etik dışı davranışın getirisi ise müşteri kaybıdır. Konaklama işletmelerinin bir diğer bölümü olan yiyecek içecek departmanında da etik açıdan bazı sorunlarla karşı karşıya kalınabilmektedir. Özellikle sanitasyon ve güvenlik ile menülerde doğruluk etik açıdan önemli konulardır. Sanitasyonun sağlanmaması durumunda yiyeceklerle ilgili bir problemde (zehirlenme gibi) müşterilerin sağlıkları ve güvenlikleri tehlike altına alınmış olacaktır. Bununla beraber menülerde yazılan bilgiler (cins, isim, miktar, fiyat) ile sunulan yiyecek içecek hizmetinin farklı olması bir diğer etik sorundur.

Seyahat işletmelerinde yaşanan etik sorunlar ise daha çok vaad edilen hizmet ile sunulan hizmet arasındaki farklılıktan kaynaklanmaktadır. Seyahat işletmelerinin de kendilerini garantiye aldıkları bazı uygulamalar vardır. Örneğin ücretini ödemiş fakat seyahate katılamayacak bir müşteriye ücretin düşük bir kısmı ödenir veya ödeme yapılmaz. Çünkü kalan kısıtlı zamanda seyehat işletmesinin bu seyehat paketini satıp satamayacağı kesin değildir. Öte yandan seyehat işletmelerinin tüketiciyi aldatması (broşür, reklam vb.) etik olmayan ve düzeltilmesi gereken bir konudur.

Turizm işletmelerinin etik ilkeler doğrultusunda yönetilmesi, turizmden elde edilecek faydayı arttıracaktır. Fakat etik ilkeler doğrultusunda yönetilmediğinde ise, müşteri tatminsizliğine yol açacaktır. Bununla birlikte personele etik davranılmadığı takdirde personel müşteriye ve çalışma arkadaşlarına etik davranmayacak bu da müşteri tatminsizliği ve işletme başarısızlığına neden olacaktır.

Çalışmanın literatüre katkıda bulunmasının yanında konuyla ilgilenen araştırmacılara fikir sağlayacağı düşünülmektedir. Ayrıca konaklama ve seyahat işletmelerinin etik sorunlar üzerinde daha fazla durmaları ve hassasiyet göstermeleri ile bünyesinde bulunan işgörenleri etik konusunda bilinçlendirmelerini sağlamak beklenen diğer sonuçlar arasındadır. Bu kapsamda konaklama ve seyahat işletmesi yöneticileri ile turizm eğitimi veren kurumlara şu önerilerde bulunulabilir:

- Söz konusu işletmelerde çalışan personele etik hakkında eğitim verilmelidir. Bu kapsamda işletme bünyesinde bulunan insan kaynakları departmanı bu konuda personeli yönlendirmelidir.

- Çalışanlara, etik davranışın gerek toplum açısından gerekse çalışan-müşteri ilişkisi açısından önemi anlatılmalı, çalışanlar bilinçlendirilmelidir.

- Broşür ve kataloglarda aldatıcı ve yanıltıcı bilgiler verilmemeli, abartılı fotoğraflardan kaçınılmalıdır.

- İşletmelerde gerek çalışanların gerekse müşterilerin uyması gereken etik kurallar belirlenmeli ve bu kurallara uyulması sağlanmalıdır.

- Kültür ve Turizm Bakanlığı ile TÜRSAB (Türkiye Seyahat Acentaları Birliği) tarafından etik konular ile ilgili seminerler verilmelidir.

- Turizm alanında ortaöğretim ve yükseköğretim düzeyinde öğrenim gören öğrencilere, etik başlı başına bir ders olarak verilmelidir. 


\section{Kaynakça}

Akoğlan Kozak, M. \& Güçlü, H. (2006). Turizmde etik (kavramlar, ilkeler, standartlar). Ankara: Detay Yayıncılık.

Akova O. \& Çalık İ. (2008). Turizm eğitimi alan öğrencilerin etik algılamaları üzerine bir araştırma. Ístanbul Üniversitesi Sosyal Bilimler Dergisi, (1), 1-13.

Akyol, B. (2010). Seyahat acentalarinda çalışan personeli etik dışı davranışa yönelten faktörler, (Yayımlanmamış Yüksek Lisans Tezi). Adnan Menderes Üniversitesi/Sosyal Bilimler Enstitüsü, Aydın

Altuğ, N. \& Güler, E. G. (2003). Pazarlama etiği: hizmet pazarlamasında karşılaşılan etik sorunlar ve malların pazarlamasından farklılıkları. I. Türkiye Uluslararası İş ve Meslek Ahlakı Kongresi Bildirileri, Ankara, 321-327.

Aşar, D. (2018). Tüketicilerin seyahat acentaları web tabanlı uygulamalarını etik yönden değerlendirmeleri, (Yayımlanmamış Yüksek Lisans Tezi). Erciyes Üniversitesi/ Sosyal Bilimler Enstitüsü, Kayseri

Aydın, E., Şimşek, A. \& Çilesiz E. (2016). Potansiyel iş gücü olarak turizm öğrencilerinin etik eğilimlerinin belirlenmesi: Atatürk Üniversitesi Turizm Fakültesine yönelik bir uygulama. Turizm ve Araştırma Dergisi, 5,(2), 20-42.

Demirçivi, B. M. (2013). Turizmde küresel etik kodlarl: seyahat acentesi yönetici görüşlerinin değerlendirilmesi, (Yayımlanmamış Doktora Tezi). Gazi Üniversitesi/Eğitim Bilimleri Enstitüsü, Ankara

Ekiztepe, B. (2011). Konaklama işletmelerinde etik iklimi, örgütsel adalet ve örgütsel bağlllık iliş̧kisi, (Yayımlanmamış Yüksek Lisans Tezi). Muğla Üniversitesi/Sosyal Bilimler Enstitüsü, Muğla

Karayiğit, Ç. (2004). Beş yıldızlı otel işletmelerinde çalışanların etik davranışları üzerine bir uygulama, (Yayımlanmamış Yüksek Lisans Tezi). Dokuz Eylül Üniversitesi/Sosyal Bilimler Enstitüsü, İzmir

Kılınç, İ. (2000). İş etiği kapsamında otel yöneticilerinin çalışanlara karşı etik sorumlulukarının İzmir'de turizm işletmeciliği ve otelcilik öğrenimi gören öğrencilerin bakış açıları ile değerlendirilmesi. Dokuz Eylül Üniversitesi Sosyal Bilimler Enstitüsü Dergisi, 2(3), 94104.

Lee, Yee-Sum Lousia \& Tsang, K.F. Nelson. (2013). Perceptions of tourism and hotel management students on ethics in the workplace. Journal Of Teaching In Travel \& Tourlsm, 13(3), 228-250.

Ma, C. Fangying; Ma, S. Wei; Wu, Liyun \& Ma Ma, Ming. (2013). İnfluence of empirical work on the job-related ethics of hotel interns: a case study of students in mainland China. Journal Of Hospitality \& Tourism Education, 25(2), 57-66.

Menekşe, R. (2007). Ankara'da faaliyet gösteren a grubu seyahat acentalarında çalışmakta olan personelin tüketiciye karşı etik davranışları algılama düzeyleri üzerine ampirik bir araştırma, (Yayımlanmamaış Yüksek Lisans Tezi). Gazi Üniversitesi/Eğitim Bilimleri Enstitüsü, Ankara

Menekşe, R. (2008). Ankara' da faaliyet gösteren a grubu seyahat acentalarında çalışmakta olan personelin tüketiciye karşı etik davranışlarını algılama düzeyleri üzerine ampirik bir araştırma. Ekonomik ve Sosyal Araştırmalar Dergisi, 4(1), 83-117.

Meriç, S. (2013). Girişimcilik potansiyeli ile etik algı arasındaki ilişki: akçakoca turizm işletmeciliği ve otelcilik yüksekokulu örneği, (Yayımlanmamış Yüksek Lisans Tezi). Düzce Üniversitesi/Sosyal Bilimler Enstitüsü, Düzce

Olcay A. \& Sürme M. (2015). Turizm işletmelerinde yönetici ve işgören etik davranışlarının karşılaştırılması üzerine bir araştırma. Uluslararası Sosyal Araştırmalar Dergisi, 8(37), 1114- 1131.

Öncel, A. (2010). Turistik bölgelerde hava limanlarında görevli güvenlik personelinin etik 
kuralları algılama biçimlerinin değerlendirilmesi (İstanbul ve Antalya örneği), (Yayımlanmamış Yüksek Lisans Tezi). Sakarya Üniversitesi/Sosyal Bilimler Enstitüsü, Sakarya

Sarışık, M., Akova, O. \& Çontu, M. (2006). Otel yöneticilerinin etik politika ve yöntemlere yaklaşımları üzerine ampirik bir araştırma. Anatolia: Turizm Araştırmaları Dergisi, 17(1), 22-34.

Sökmen, A. \& Tarakçıoğlu, S. (2004). Yönetici etik davranışlarının değerlendirilmesinde cinsiyet faktörü: Ankara'daki otel işletmelerinin sınır departmanlarında amprik bir araştırma. I. Balıkesir Ulusal Turizm Kongresi, 15-16 Nisan 2004, Balıkesir, 216-250.

Sroka, W. \& Lörinczy, M. (2015). The perception of ethics in business: analysis of research results. Precedia Economics and Finance, 34, 156-163.

Sürme, M. (2015). Turizm ĕgitimi alan öğrencilerin staj eğitimi sürecinde yönetici ve işgören davranışlarının etik boyutunu değerlendirmeleri üzerine bir araştırma, (Yayımlanmamış Yüksek Lisans Tezi). Gaziantep Üniversitesi/Sosyal Bilimler Enstitüsü, Gaziantep

Şahin, B. (2011). Seyahat acentalarının pazarlama faaliyetlerinde etik karar verme süreci: İstanbul örnegi, (Yayımlanmamış Doktora Tezi). Balıkesir Üniversitesi/Sosyal Bilimler Enstitüsü, Balıkesir

Tarakçıŏglu, S. (2003). Yönetici etik davranışlarının değerlendirilmesinde cinsiyet faktörü: Ankara'daki otel işletmelerinin sınır departmanlarında amprik bir araştırma. Gazi Üniversitesi Ticaret ve Turizm Ë̆itimi Fakültesi Dergisi, 2, 180-219.

Torun, M. K. (2013). Turizm alanında lisans ve önlisans eğitimi veren kurumlarda etik iklimin kuruma güven üzerindeki etkisi, (Yayımlanmamış Yüksek Lisans Tezi). Düzce Üniversitesi/Sosyal Bilimler Enstitüsü, Düzce

Tsalikis J. \& Fritzsche D. J. (1989). Business ethics: a literature review with a focus on marketing ethics. Journal Of Business Ethics, 8, 695-743.

Uçkun, G, Uçkun, S, \& Latif, H. (2004). Turizmde etik, Sakarya: Sakarya Kitabevi.

Velasquez, M. G. (2002). Business ethics: conceptsand cases. New Jersey: Brentice Hall.

Yarcan, Ş. (2007). Profesyonel Turist Rehberliğinde Mesleki Etik Üzerine Kavramsal Bir Değerlendirme. Anatolia: Turizm Araştırmaları Dergisi, 18(1), 33-44.

Yeung, S. (2004), Hospitality ethics curriculum: an industry perspective. International Journal Of Contemporary Hospitality Management, 16(4), 253-262.

Yılmazer, A. \& Bahadır, İ. (2011). Otel işletmelerinde önbüro çalışanlarının etik algılamalarına yönelik bir araştırma. Çukurova Üniversitesi Sosyal Bilimler Enstitüsü Dergisi, 20(3), 21-40.

Wong, K. C. Simon. (1998). Staff job_related ethics of hotel employees in hong kong. International Journal of Contemporary Hospitality Management, 10(3), 107-115.

\section{Internet Kaynakları}

http://www.tdk.gov.tr/index.php?option=com_gts\&arama=gts\&guid=TDK.GTS.5b0ea6c2869 ec7.86806134 Erişim Tarihi: 01/06/2018.

http://www.tdk.gov.tr/index.php?option=com_gts\&arama=gts\&guid=TDK.GTS.5b33fbbccd0 555.14547932 Erişim Tarihi: 28/06/2018. 